\title{
Scaffolding Model in Learning of Writing of Essays, Based on Experience
}

\author{
Mersty Rindengan \\ Elementary School Teacher Education Dept \\ Universitas Negeri Manado, Indonesia \\ merstyrindengan@unima.ac.id
}

\begin{abstract}
The purpose of this study was to determine the effect of the scaffolding learning model on the learning outcome of writing essays based on experience. This study used an experimental research method with a pretestposttest control group design. The dependent variable is essay writing skills based on experience; the independent variable is the scaffolding learning model. The population in this study were fifth-grade students of SD GMIM IV Tomohon. Data processing in this study uses independent t-test analysis. the results of this research showed the skills of writing essays based on the experience of the group of students who were taught with the scaffolding learning model were higher than the group of students who were taught with conventional learning models, so it can conclusion the application of scaffolding learning models can give height effect or can significant improve student learning outcomes in essay writing skills based on experience.
\end{abstract}

Keywords: scaffolding learning model, skill of write essay

\section{INTRODUCTION}

In the field of Indonesian language material of writing has an important role. Every teacher in elementary school wants each student to master writing skills. Because writing skills in elementary school have a purpose, namely to copy, record, and do most of the assignments given at school in the hope of practicing language skills well [1]. Writing can also be a means of communication with contemporaries with us or with the new generation of the future, where writing works can provide a relatively permanent record of information, opinions, arguments [2].

However, The reality of the skills of students in writing are still relatively low. The ability to write is meant here is the ability to write essays based on experience. Student ability to write is different, as Murisuo found that Boys were significantly more reluctant writers than girls. To improve writing skills and students more interested to doing, learning of writing essay should have a meaningful purpose or a communicative function [3].

The lack of essay writing skills based on experience influences other language skills, so there needs to be an effort to improve essay writing skills based on experience. Increasing student's writing skills needed as done with an innovative learning model that can build students' enthusiasm. Scaffolding learning model is one of the most effective learning models for students through knowledge of the process of making assignments.

This is in accordance with what was stated by Wilson that Scaffolding learning model provides a means to enable students to complete the tasks valued by the academy; it enables learners to be task-focused in their learning — not ends-focused. That is, the activity of completing the task is constructed by both students and teachers as a learning opportunity, rather than as a task fulfillment activity [4].

The purpose of this study was to determine the effect of the scaffolding learning model on the learning outcome of writing essays based on experience and to know the differences in learning outcomes in writing essays based on the experience of the group of students taught by the scaffolding learning model and groups of students who were taught conventional learning models.

\section{METHOD}

This study used an experimental research method with a pretest-posttest control group design. The dependent variable is essay writing skills based on experience, the independent variable is the scaffolding learning model. The population in this study were fifth grade students of SD GMIM IV Tomohon. Sample in this study was a population sample [5] consisting of two classes, each VA class totalling 13 students, and VB class totalling 14 students.

Population is assumed as the same as the population unit because there are some similarities, namely: (a) having a background with knowledge and age that is almost the same; (b) has the same number of hours and school facilities; and (c) the material taught is the same. Dependent variable data were collected using an objective test in the form of a multiple choice test with a total of 50 items to determine essay writing skills in Indonesian with a score of one if the answer is correct and a score of 0 if the answer is wrong.

Prior to use the instrument was tested for validity and reliability. Testing the validity of the instrument is done in two forms, namely testing the construct validity or content is carried out with expert analysis, and empirical validity testing with item score correlations with the total score of the test results. In testing the construct validity or content the experts are asked to give an assessment in the following aspects: (1) the question items are in accordance with the indicators, (2) the questions are clearly defined, (3) the use of appropriate language, (4) the formulation of sentences does not lead to a double understanding, and (5) material compatibility. After testing the construct validity, the empirical validity test is continued using the product moment correlation formula [6]. The product moment correlation formula, as follows:

$$
r x y=\frac{N \sum x y-\left\{\sum x\right\}\left\{\sum y\right\}}{\left.\sqrt{\left\{N \sum X^{2}\right.}-\left(\sum X^{2}\right)\right\}\left\{N \sum Y^{2}-\left(\sum Y\right)^{2}\right\}}
$$


The results of the validity test was compared with the product moment critical table with a significant level of $5 \%$. If $r$ count $r$ table, the item is valid. Furthermore, to test the reliability of the instrument, the KR-20 formula is used as follows [7]:

$r_{11}=\left(\frac{n}{n-1}\right)\left(\frac{s_{t-\sum p i q i}^{2}}{s_{t}^{2}}\right)$

Testing the validity and reliability of the instrument was carried out on 10 students in class VI SD GMIM IV Tomohon. The trial was conducted by the researcher and assisted by the fifth grade teacher. Conclusion The results of the validity test stated that all items were valid because they had $\mathrm{r}$ counts greater than $\mathrm{r}$ tables and the reliability test results showed that the reliability of the questions was high because the value of $r=0.754$. Data processing in this study uses independent $t$ test analysis using the following formula:

$t=\frac{\overline{x_{1}}-\overline{x_{2}}}{\sqrt{\frac{s_{1}^{2}}{n_{1}}+\frac{s_{2}^{2}}{n_{2}}}}$

As a requirement in the comparative test, a requirement test is carried out, namely the normality and homogeneity tests. In this study a normality test was performed to determine whether the distribution of sample data analyzed was normally distributed or not. The group tested for normalization consisted of two groups, each consisting of: a group of students who were taught using the scaffolding learning model and a group of students who used a conventional learning model.

Calculation of normality test in this study using SPSS 21 program assistance. If the significance value 0.05 then the data distribution is normal [8]. Testing the homogeneity of the data using the Levene test with the help of the SPSS 21 programs. If the significance value lower than 0.05 there is no difference between the two data groups or the data is homogeneous [8].

\section{RESULTS}

Dependent variable data in this study consisted of 4 parts namely control class pretest data, control class posttest data, experimental class pretest data, experimental class posttest data. The research data are presented in Table 1 below.

Based on the data in Table 1, the results of the control class pretest had the lowest value of 10 , the highest value of 29; and for the pretest results of the experimental class had the lowest value of 11 , the highest value of 27 . While the posttest results of the control class had the lowest value of 17, the highest value of 34; and for the posttest results of the experimental class had the lowest value of 19, the highest value of 45. Furthermore, with the help of the SPSS program computer obtained descriptive statistical values as presented in Table 2.

Based on the data in Table 2, the pretest data for the control class showed an average value is 18.62 and a standard deviation value is 6.64; while the experimental class showed an average value is 17.93 and a standard deviation value is 5.731 .
Table 1

Research Data

\begin{tabular}{|c|c|c|c|}
\hline $\begin{array}{c}\text { Control } \\
\text { Class } \\
\text { Pretest }\end{array}$ & $\begin{array}{c}\text { Control } \\
\text { Class } \\
\text { Posttest }\end{array}$ & $\begin{array}{c}\text { Experimental } \\
\text { Class Pretest }\end{array}$ & $\begin{array}{c}\text { Experimental } \\
\text { Class } \\
\text { Posttest }\end{array}$ \\
\hline 10 & 17 & 11 & 19 \\
\hline 11 & 20 & 11 & 22 \\
\hline 12 & 25 & 11 & 24 \\
\hline 12 & 25 & 12 & 30 \\
\hline 14 & 25 & 14 & 31 \\
\hline 17 & 25 & 15 & 32 \\
\hline 18 & 25 & 17 & 35 \\
\hline 20 & 27 & 19 & 35 \\
\hline 21 & 30 & 20 & 36 \\
\hline 25 & 30 & 21 & 37 \\
\hline 25 & 31 & 23 & 42 \\
\hline 28 & 34 & 25 & 43 \\
\hline 29 & 34 & 25 & 44 \\
\hline & & 27 & 45 \\
\hline
\end{tabular}

Table 2

Statistic Descriptive

\begin{tabular}{|c|c|c|c|c|c|c|}
\hline \multirow{3}{*}{ Class } & \multirow{3}{*}{\multicolumn{2}{|c|}{ Statistic }} & & & & \\
\hline & & & \multicolumn{2}{|c|}{ Pretest } & \multicolumn{2}{|c|}{ Posttest } \\
\hline & & & Statistic & $\begin{array}{c}\text { Std. } \\
\text { Error }\end{array}$ & Statistic & $\begin{array}{l}\text { Std. } \\
\text { Error }\end{array}$ \\
\hline \multirow{13}{*}{ 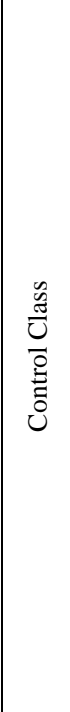 } & \multicolumn{2}{|l|}{ Mean } & 18.62 & 1.842 & 26.77 & 1.387 \\
\hline & \multirow{2}{*}{$\begin{array}{l}95 \% \text { Confidence } \\
\text { Interval for Mean }\end{array}$} & $\begin{array}{l}\text { Lower } \\
\text { Bound }\end{array}$ & 14.6 & & 23.75 & \\
\hline & & $\begin{array}{l}\text { Upper } \\
\text { Bound }\end{array}$ & 22.63 & & 29.79 & \\
\hline & \multicolumn{2}{|l|}{$5 \%$ Trimmed Mean } & 18.52 & & 26.91 & \\
\hline & \multicolumn{2}{|l|}{ Median } & 18 & & 25 & \\
\hline & \multicolumn{2}{|l|}{ Variance } & 44.09 & & 25.026 & \\
\hline & \multicolumn{2}{|l|}{ Std. Deviation } & 6.64 & & 5.003 & \\
\hline & \multicolumn{2}{|l|}{ Minimum } & 10 & & 17 & \\
\hline & \multicolumn{2}{|l|}{ Maximum } & 29 & & 34 & \\
\hline & \multicolumn{2}{|l|}{ Range } & 19 & & 17 & \\
\hline & \multicolumn{2}{|l|}{ Interquartile Range } & 13 & & 6 & \\
\hline & \multicolumn{2}{|l|}{ Skewness } & 0.242 & 0.616 & -0.292 & 0.616 \\
\hline & \multicolumn{2}{|l|}{ Kurtosis } & -1.38 & 1.191 & -0.127 & 1.191 \\
\hline \multirow{13}{*}{ 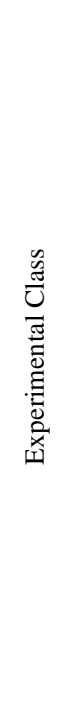 } & \multicolumn{2}{|l|}{ Mean } & 17.93 & 1.473 & 33.08 & 2.188 \\
\hline & \multirow{2}{*}{$\begin{array}{l}95 \% \text { Confidence } \\
\text { Interval for Mean }\end{array}$} & $\begin{array}{l}\text { Lower } \\
\text { Bound }\end{array}$ & 14.02 & & 28.31 & \\
\hline & & $\begin{array}{l}\text { Upper } \\
\text { Bound }\end{array}$ & 20.44 & & 37.84 & \\
\hline & \multicolumn{2}{|l|}{$5 \%$ Trimmed Mean } & 17.15 & & 33.25 & \\
\hline & \multicolumn{2}{|l|}{ Median } & 17 & & 35 & \\
\hline & \multicolumn{2}{|l|}{ Variance } & 28.192 & & 62.244 & \\
\hline & \multicolumn{2}{|l|}{ Std. Deviation } & 5.31 & & 7.889 & \\
\hline & \multicolumn{2}{|l|}{ Minimum } & 11 & & 19 & \\
\hline & \multicolumn{2}{|l|}{ Maximum } & 25 & & 44 & \\
\hline & \multicolumn{2}{|l|}{ Range } & 14 & & 25 & \\
\hline & \multicolumn{2}{|l|}{ Interquartile Range } & 11 & & 13 & \\
\hline & \multicolumn{2}{|l|}{ Skewness } & 0.195 & 0.616 & -0.37 & 0.616 \\
\hline & \multicolumn{2}{|l|}{ Kurtosis } & -1.487 & 1.191 & -0.659 & 1.191 \\
\hline
\end{tabular}

Furthermore, the post-test data for the control class showed an average value is 26.77 and a standard deviation value is 5.003; while the experimental class showed an average value is 33.08 and a standard deviation value is 
7.889. This research uses comparative analysis. Normality and homogeneity of the data were tested as a prerequisite analysis. Data normality test results are presented in Table 3 below.

Table 3

Tests of Normality

\begin{tabular}{|l|c|c|c|c|c|c|}
\hline \multirow{2}{*}{ Groups } & \multicolumn{3}{|c|}{$\begin{array}{c}\text { Kolmogorov- } \\
\text { Smirnov }\end{array}$} & \multicolumn{3}{c|}{ Shapiro-Wilk } \\
\cline { 2 - 7 } & Statistic & df & Sig. & Statistic & df & Sig. \\
\hline Pretest Control & .148 & 13 & $.200^{*}$ & .925 & 13 & .292 \\
\hline Pretest Experiment & .145 & 13 & $.200^{*}$ & .901 & 13 & .140 \\
\hline Posttest Control & .208 & 13 & .128 & .931 & 13 & .355 \\
\hline Posttest Experiment & .135 & 13 & $.200^{*}$ & .949 & 13 & .584 \\
\hline
\end{tabular}

Based on the data in Table 3, the results of the normality test of the four data groups show a significance value greater than 0.05 . This gives the sense that all four data groups are normally distributed. Homogeneity test results of pretest data and comparative analysis using the independent t-test are presented in table 4 below.

Based on the data in table 4 , the Levene test results show the significant value of the homogeneity test is 0.562 $>0.05$. The homogeneity test results of the pretest data state that the data of both the homogeneous group or the control class group and the experimental group have the same population variance.

With the fulfillment of normality and homogeneity tests of data from two groups, namely the control class and the experimental class, then a comparative test using an independent t-test can be carried out. The comparative test results using the independent $t$-test on the pretest data in table 4 show that the significant value is $0.775>0.005$. This means that there is no significant difference in the skills of writing essays based on experience between the two groups before the treatment.

Table 4

Homogeneity Test and T Test of Pretest Data

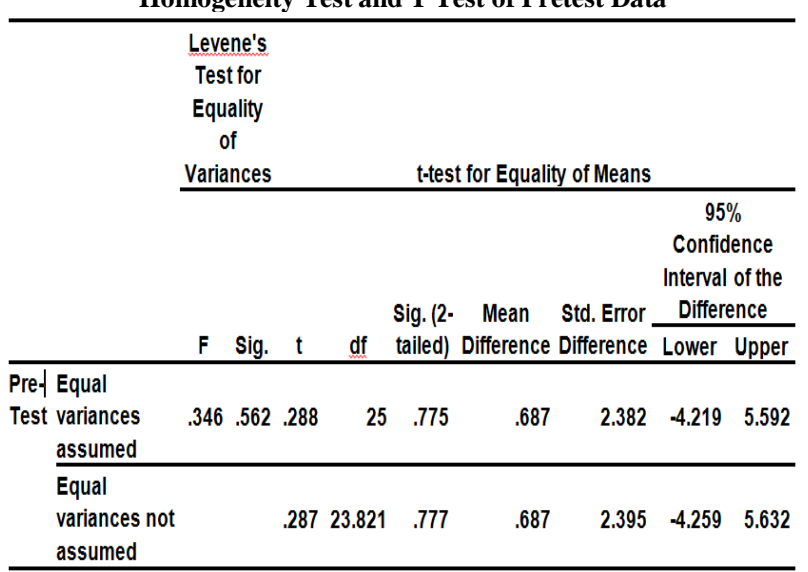

Next, we discussed the effect of scaffolding learning models on the skills of write essays based on experience in fifth-grade students of SD GMIM IV Tomohon. The influence is seen from the difference in the skills to write essays based on the experience of each group of students in the experimental class and the control class. The difference in the average value of the post-test of the experimental class and the control class is presented in Figure 1.

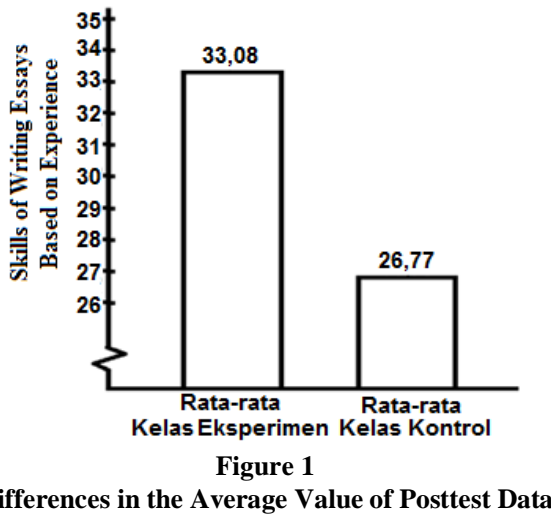

From the Figure 1, visible differences in the average value of the two groups, where the skills of write essays of groups of students who are taught with scaffolding learning models are higher than the ability to write the essay using conventional learning models. Essay writing skills of the two groups before learning based on pretest data did not differ significantly. but after treatment, which the student group in the experimental class carries out the learning that applies the scaffolding learning model and the group of students in the control class carries out learning with the conventional learning model, had different the learning outcomes in skills of writing essays as shown in Figure 1. This is supported by the gain data obtained by the two groups. The gain data for the two groups are presented in Table 5 and the difference in average gain is presented in Figure 2.

Table 5

Data Gain

\begin{tabular}{|c|c|c|}
\hline Number & Control Class & Experiment Class \\
\hline 1 & 7 & 6 \\
\hline 2 & 9 & 9 \\
\hline 3 & 13 & 14 \\
\hline 4 & 13 & 13 \\
\hline 5 & 11 & 11 \\
\hline 6 & 8 & 10 \\
\hline 7 & 7 & 8 \\
\hline 8 & 7 & 8 \\
\hline 9 & 9 & 10 \\
\hline 10 & 5 & 9 \\
\hline 11 & 6 & 8 \\
\hline 12 & 6 & 9 \\
\hline 13 & 5 & 9 \\
\hline 14 & - & 27 \\
\hline Average & $\mathbf{8 . 1 5}$ & $\mathbf{1 0 . 7 9}$ \\
\hline
\end{tabular}

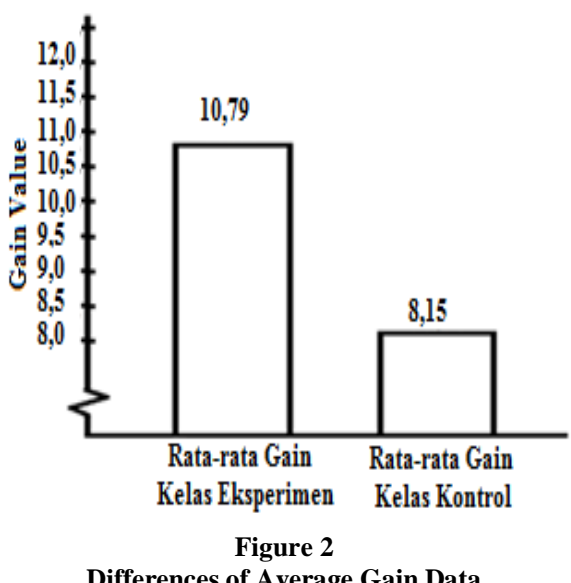


The difference in the average value of gain data is clearly seen in Figure 2, it is showed the application of the scaffolding learning model gives a greater influence on essay writing skills compared to the application of conventional learning models to find out more clearly the significance of the differences between the two groups, Independent t-test was conducted performed on the posttest data of the two groups. The independent t-test results are presented in Table 6.

Table 6

Independent $\mathrm{T}$ Test of Posttest Data

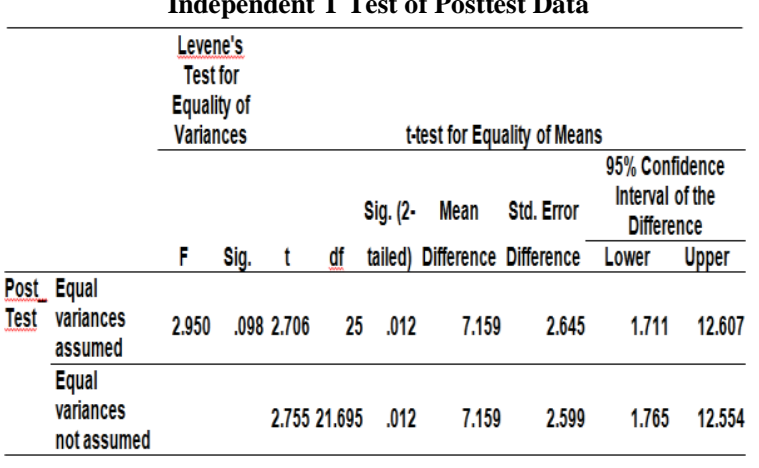

Based on data in Table 6 , the independent t-test results show that $\mathrm{t}$-count $=2.706>\mathrm{t}$-table $=2.145$ and significant value $(2$-tailed $)=0.012<0.05$. This concludes that the H0 was rejected and accepted the research hypothesis which stated that the skills of writing essays based on the experience of the group of students who were taught with the scaffolding learning model were higher than the group of students who were studied with conventional learning models.

\section{DISCUSSION}

This research is an attempt to determine the effect of scaffolding learning models on the ability to write essays based on the experience of the student. Scaffolding instruction is a branch of the constructivist teaching theory, which emphasizes the students as the center, and in the context of collaborative learning [9]. The writing skills of each student possessed after learning in elementary school are more specific in class $\mathrm{V}$, which is one of the basic abilities that can support the student's performance in the future. This is because essay writing skills are the result of psychomotor learning from students which can be applied in various fields and are an important component in achieving adult performance [10].

The Emphasis of Learning which aims to provide the understanding and essay writing skills based on this experience is in the learning process. In the learning process the teacher carries out learning activities that can motivate them by giving questions to students about the theme and title of the essay written and continued by listening to the concept predicted by the student then the teacher re-directs it in exploration activities and elaboration. the teacher does end the learning activities with confirmation activities, the teacher discusses things that are not understood by students. The learning process that applies the scaffolding learning model makes students learn through questions, observations and information exchange, while the teacher ensures students gradually complete the assignment [9]. This scaffolding learning requires the teacher to design several learning scaffolds by predicting the level of student ability that can facilitate student independent learning [11].

In this learning process, students learn from experience gained in the learning process either through teacher guidance or through discussions that occur between the teacher and students; between students and students and through the process of making independent assignments. this learning proses provides knowledge as well as skills that can last a long time and become a capital for student performance in the future.

The results of learning process in this study shows that the teacher's role is very large in efforts to make students achieve maximum learning outcomes, or in other words learning management has an effect on teacher performance [12], and teacher teaching performance has a significant in learning achievement [13]. Through the learning outcomes obtained in this study in the form of essay writing skills scores indicated that the application of the scaffolding learning model provides a significant increase in learning outcomes.

\section{CONCLUSION}

The application of scaffolding learning models can give effect or can improve student learning outcomes in essay writing skills based on experience. The skills of writing essays based on the experience of the group of students who were taught with the scaffolding learning model were higher than the group of students who were taught with conventional learning models.

\section{ACKNOWLEDGMENT}

Thank you to Universitas Negeri Manado for giving me the task to research and publish the results of this research. thank you conveyed to the principal of Tomohon GMIM IV elementary school and teachers and students who have helped a lot in the research process so that researchers can complete this research. thank you to the Universitas Negeri Malang which hosted the FIP-JIP event and became a committee in publishing this scientific work.

\section{REFERENCES}

[1] Adurrahman. 2000. Writing Skills. Yogyakarta: PT Persada Jaya.

[2] Huy, N. T. 2015. Problems affecting learning writing skill of grade 11 at Thong Linh High School. Asian Journal of Educational Research, 3(2), 1-19.

[3] Merisuo-Storm, T. G. 2006. Boys like to read and write different texts. Scandinavian Journal of educational research, 50(2), 111-25.

[4] Wilson, K., \& Devereux, L. 2014. Scaffolding theory: High challenge, high support in Academic Language and Learning (ALL) contexts. Journal of Academic Language and Learning, 8(3),91-100.

[5] Acharya, A. S. 2013. Sampling: Why and How of It? Indian Journal of Medical Specialties, 4(2), 1-10.

[6] Hauke, J., \& Kossowski, T. 2011. Comparison of values of Pearson's and Spearman's correlation coefficients on the same sets of data. Quaestiones geographicae, 30(2), 87-93.

[7] Tan, S. 2009. Misuses of KR-20 and Cronbach's alpha reliability coefficients. Egitim ve Bilim, 34(2), 101-107.

[8] Priyatno, D. 2010. 5 hours of studying SPSS 19 data processing. Yogyakarta: Andi. 
[9] Gao, Y. 2016. The Study for the Combination of Scaffolding Instruction and Flipped Classroom Model. In International Conference on Education, Management, Computer and Society, Atlantis Press.

[10] Applebee, A. N., \& Langer, J. A. 1983. Instructional scaffolding: Reading and writing as natural language activities. Language arts, 60(2), 168-75.

[11] Goodwin, B., \& Miller, K. 2010. Research says evidence on Flipped Classrooms is still coming in. Technology Rich Learning, 70(6), 78-80.
[12] Tuerah, R. M. 2017. Analysis of Teacher Performance on Learning Managment in Primary School. In 9th International Conference for Science Educators and Teachers (ICSET 2017), Atlantis Press.

[13] Yulianingsih, L. T., \& Sobandi, A. 2017. Kinerja mengajar guru sebagai faktor determinan prestasi belajar siswa. Jurnal Pendidikan Manajemen Perkantoran, 2(2), 49-56. 